\title{
Recovery of Antioxidant Compounds from Aronia Filter Tea Factory by -Product: Novel Versus Conventional Extraction Approaches
}

\author{
Aleksandra Gavaric, Milica Ramic, Jelena Vladic, Branimir Pavlic, \\ Robert Radosavljevic and Senka Vidovic ${ }^{*}$
}

Faculty of Technology, University of Novi Sad, 21000, Bulevar cara Lazara 1, Novi Sad, Serbia

* Corresponding author: E-mail: senka.curcin@yahoo.com

$+381214853731$

Received: 19-01-2018

\begin{abstract}
Black chokeberry (Aronia melanocarpa L.) by-product from filter tea factory underwent subcritical water extraction (SWE) in order to recover polyphenolics and determine its antioxidant potential. In the current study Box-Behnken design was applied for optimization. Independent variables used in experimental design were temperature ( $T, 120-200$ ${ }^{\circ} \mathrm{C}$ ), extraction time (t, 15-35 min) and hydrochloride concentration (c, 0-1.5\%). Experimental results were fitted to a second-order polynomial model where multiple regression analysis and analysis of variance were used to determine fitness of the model and optimal conditions. The optimized SWE conditions for maximum responses of total phenols (TP), total flavonoids (TF) and monomeric anthocyanins (MA) contents, and minimum response of $\mathrm{IC}_{50}$ were temperature of $120.4^{\circ} \mathrm{C}$, extraction time of $15.2 \mathrm{~min}$ and absence of acidifier. The predicted values of TP, TF, MA and $\mathrm{IC}_{50}$ at these conditions were: $32.8863 \mathrm{mg} \mathrm{GAE} / \mathrm{g}, 23.5164 \mathrm{mg} \mathrm{CE} / \mathrm{g}, 0.5124 \mathrm{mg} \mathrm{C} 3 \mathrm{G} / \mathrm{g}$ and $0.0055 \mathrm{mg} / \mathrm{mL}$, respectively.
\end{abstract}

Keywords: Aronia melanocarpa L.; subcritical water extraction; antioxidants; response surface methodology; optimization

\section{Introduction}

Aronia melanocarpa L. (commonly known as black chokeberry) is a perennial shrub which originates from North America. ${ }^{1}$ Aronia berries are one of the richest plant sources of anthocyanins, mainly containing cyanidin glycosides, ${ }^{2}$ which constitutes $25 \%$ of the total polyphenols. ${ }^{3}$ This member of Rosaceae family is also recognizable for possessing the highest in vitro antioxidant capacity among berries. ${ }^{4}$ Besides anthocyanins, chokeberries are abundant in proanthocyanidins and hydroxycinamic acid. ${ }^{5}$ Dominant proanthocyanidins are epicatechin oligomers, which have share of $66 \%$ in aronia fruit polyphenols. ${ }^{3}$ There is a growing interest in utilization of anthocyanins and proanthocyanidins, due to their antioxidant potential and positive correlation between their consumption and prevention of colon cancer, cardiovascular disease, ${ }^{1}$ diabetes mellitus type II and hepatoprotective effect. ${ }^{6}$ Beside use of aronia berries in medical purposes it is widely exploited in the food industry, either on its own, or mixed with other fruits (e.g. in juices, syrups, jams, wine production, food colouring, dietary supplements). ${ }^{7,8}$

Today, biowaste streams e.g. low volume agro-food waste streams like leaves, stems, bulbs, flowers and exhausted cakes pose environmental risks while being an important potential feedstock resource for producing a wide range of novel bioproducts. Their utilization is limited by the lack of technologies able to process heterogeneous mixtures beyond existing technologies, that fully break down the valuable complexity of components, or specific extraction and separation technologies, which are excessively costly. In the production of aronia juice, after extraction step, many phenolic compounds including anthocyanins are still present in the cake and could be valorized by adequate extraction process. Therefore, solids left after production of aronia juice in fruit factory are used as a raw material for the production of fruit filter tea.

Dry aronia cake underwent several processes: cutting, grinding, milling, sifting and fractionating. After these technological processes approximately $20 \%$ of input batch is of particle size lower than the particle size of pores 
of filter tea bag. Since this fraction cannot be packed into filter bags it represents by-product also known as fruit dust. As this material has particle size lower than 0.315 $\mathrm{mm}$, it could be successfully used for extraction as plant particles with low particle size represent a convenient crude material for extraction. The main reason for that is increased mass transfer of bioactives from powdered plant material to liquid phase. ${ }^{9}$

Solvent extractions are the most common extraction methods for phenolic compounds. Solvents such as ethanol, methanol, acetone, ethyl acetate, as well as their combination and mixture in different proportion with water are the most often used solvents in classical extractions. ${ }^{10}$ Classical methods of extraction, apart from using solvents with negative environmental impact, very often exert low selectivity and efficiency of extraction as well as long extraction time. Additionally, further processing of obtained liquid extracts is necessary in order to removal of the solvents. Subcritical water extraction (SWE) is a green solvent extraction technique which uses water at temperatures between 100 and $374{ }^{\circ} \mathrm{C}$ and pressure high enough to keep it in the liquid state. ${ }^{11}$ Water on room temperature is an inadequate extraction solvent for phenolic compounds, due to high dielectric constant. However, variations of temperature allow modification of dielectric constant of water in that way altering its selectivity. At elevated temperature, the initial value of dielectric constant of 80 at $25^{\circ} \mathrm{C}$ decreases to 27 at $250^{\circ} \mathrm{C}$ which falls between those of ethanol $(\varepsilon=24)$ and methanol $(\varepsilon=33)$ at $25^{\circ} \mathrm{C} .{ }^{12}$ Therefore, subcritical water is successfully employed for phenols extraction from different sources. ${ }^{13-18}$ In a great deal of studies its advantage considering extraction efficiency comparing to classical technologies has been confirmed. ${ }^{14,16,19}$ Furthermore, SWE reduces energy consumption by $3-5$ folds when compared to traditional solvent extraction. ${ }^{20}$ However, long exposure of material to high temperatures can cause oxidization of phenolic compounds. Hence, it is necessary to select the most appropriate extraction method and optimize the process in order to achieve maximal extraction efficiency and highest quality of obtained extracts. ${ }^{10}$

The main purpose of this study was to investigate the advantages of green extraction technology, subcritical water extraction, over conventional extraction technique in attempt to valorize aronia fruit dust as alternative source of dietary antioxidants. Another reason for choosing aronia filter tea by-product for this investigation is due to its convenient chemical profile regarding polyphenols, mostly anthocyanins and procyanidins responsible for positive effects on human health.

\section{Materials and Methods}

\section{1. Plant Material and Chemicals}

The chokeberry fruit dust was purchased from Fructus (Backa Palanka, Serbia), a local filter tea factory, and stored in paper bags at a room temperature until analysis. Fraction with particle size lower than filter tea bag, i.e. herbal dust, was used as a raw material for the production of chokeberry fruit filter-tea. Moisture content of dried chokeberry powder was $8.66 \%$.

Folin-Ciocalteu reagent, ( \pm )-catechin and 1,1-diphenyl-2-picryl-hydrazyl-hydrate (DPPH) were purchased from Sigma (Sigma-Aldrich GmbH, Steinheim, Germany). Gallic acid was purchased from Sigma (St. Louis, MO, USA). All other chemicals used were of analytical reagent grade.

\section{2. Maceration}

Traditional extraction procedure was performed by maceration of $10.0 \mathrm{~g}$ of chokeberry fruit dust with 30,50 and $70 \%$ ethanol $(1: 10 ; \mathrm{m} / \mathrm{v})$ at room temperature $\left(25^{\circ} \mathrm{C}\right)$ for $24 \mathrm{~h}$. Extraction was performed in shaker with temperature control (KS 4000i, IKA, Germany), and shaking (150 $\mathrm{rpm}$ ) was used in order to agitate extraction. After extraction, extracts were immediately filtered through filter paper under vacuum (V-700, Büchi, Switzerland). Extracts were collected into glass flasks and stored at $4{ }^{\circ} \mathrm{C}$ until the analysis.

\section{3. SWE Procedure}

SWE was performed in batch-type high-pressure extractor (Parr Instrument Company, USA) with internal volume $450 \mathrm{~mL}$, and maximum temperature $200^{\circ} \mathrm{C}$, connected with temperature controller (4838, Parr Instrument Company, USA). Extraction procedure was described elsewhere. ${ }^{21}$ Temperature $\left(\mathrm{T}, 120-200^{\circ} \mathrm{C}\right)$, extraction time (t, 15-35 min) and $\mathrm{HCl}$ concentration (c, 0-1.5\%) were independent variables. Operating pressure of 30 bar was kept constant. This pressure was slightly in excess of that required (20 bar) to prevent the formation of steam within the extraction cell. During extraction period, temperature was held constant (stationary phase) for different extraction time depending on experimental run. After the extraction, extractor was cooled in ice-bath during approximately $5 \mathrm{~min}$ to reach room temperature. After extraction, extracts were immediately filtered through filter paper under vacuum, collected into glass flasks and stored at $4{ }^{\circ} \mathrm{C}$ until the analysis.

\section{4. Total Phenols (TP) and Flavonoids Content (TP)}

TP content in obtained liquid extracts was determined using Folin-Ciocalteu procedure. ${ }^{22}$ Content of phenolic compounds was expressed as $\mathrm{mg}$ of gallic acid equivalents (GAE) per g dry weight (DW). Total flavonoids content was determined using aluminum chloride colorimetric assay. ${ }^{23}$ All experiments were performed in triplicate, and results are expressed as mean values. 


\section{5. Determination of Monomeric Anthocyanins Content (MA)}

MA content in the samples was estimated using a VIS-spectrophotometer by the $\mathrm{pH}$ differential method reported by Abu Bakar et al. ${ }^{24}$ with slight modifications. ${ }^{25}$ Two buffer systems, potassium chloride buffer, $\mathrm{pH} 1.0$ $(0.0025 \mathrm{M})$ and sodium acetate buffer, $\mathrm{pH} 4.5(0.4 \mathrm{M})$, were used. Briefly, $400 \mu \mathrm{L}$ of sample (diluted liquid extract) was added in $3.6 \mathrm{~mL}$ of corresponding buffer solutions and absorbance was measured against a blank probe at 510 and $700 \mathrm{~nm}$. Absorbance (A) was calculated as:

$$
A=\left(A_{510}-A_{700}\right) p H_{1.0}-\left(A_{510}-A_{700}\right) p H_{4.5}
$$

Anthocyanin concentration in the extract was calculated and expressed as cyanidin-3-glycoside equivalent (C3G):

$$
M A=(A \cdot M W \cdot D F \cdot 1000) / M a
$$

where is difference in absorbance, is a molecular weight for cyanidin-3-glucoside $(449.2 \mathrm{~g} / \mathrm{mol})$, is the dilution factor of the samples and is the molar absorptivity of cyanidin-3-glucoside $(26.900 \mathrm{M} / \mathrm{cm})$. Results were expressed as $\mathrm{mg}$ of cyanidin-3-glucoside equivalents per $\mathrm{g} \mathrm{DW}$.

\section{6. DPPH Assay}

Free radical scavenging activity of samples was determined using DPPH assay, previously described by Espin et al. ${ }^{26} \mathrm{~A}$ certain volume of diluted sample was mixed with $95 \%$ methanol and $90 \mu \mathrm{M}$ 1,1-diphenyl-2-picryl-hydrazyl (DPPH) in order to obtain different final concentrations. After incubation on room temperature for $60 \mathrm{~min}$, the absorbance was measured at $515 \mathrm{~nm}$ and result was expressed as radical scavenging capacity (RSC, \%) which was calculated using following equation:

$$
\% \text { RSC }=100-\frac{\left(A_{\text {sample }} \times 100\right)}{A_{\text {blank }}}
$$

where $A_{\text {sample }}$ is the absorbance of sample solution and $A_{\text {blank }}$ is the absorbance of blank probe. Antioxidant activity was further expressed as inhibition concentration at $50 \%$ of RSC value $\left(\mathrm{IC}_{50}\right) . \mathrm{IC}_{50}$ represents the concentration of plant extract required to obtain $50 \%$ of radical scavenging capacity, expressed as $\mathrm{mg}$ per $\mathrm{mL}$. All experiments were performed in triplicate, and results are expressed as mean values.

\section{7. Box-Behnken Design and Statistical Analysis}

The extraction efficiency of subcritical chokeberry extract can be influenced by variety of factors such as pressure, temperature, extraction time, $\mathrm{pH}$ and volume of the solvent and time of the static extraction. In the current study RSM coupled with Box-Behnken design (BBD) was applied in order to optimize SWE process. Design consisted of fifteen randomized runs with three replicates at the central point. Independent variables used in experimental design were temperature $\left(\mathrm{T}, 120-200^{\circ} \mathrm{C}\right)$, extraction time (t, 15-35 min) and hydrochloride concentration (c, $0-1.5 \%)$. In order to normalize parameters, each of the coded variables was forced to range from -1 to 1 , so that they all affect the response more evenly, and so the units of the parameters are irrelevant. ${ }^{27}$ The natural and coded values of independent variables used in BBD are presented in Table 1.

Table 1. Experimental domain with natural and coded values of independent variables used in BBD

\begin{tabular}{lccc}
\hline Independent variable & \multicolumn{2}{l}{ Factor levels } & \\
\hline & $\mathbf{- 1}$ & $\mathbf{0}$ & $\mathbf{1}$ \\
\hline Temperature $\left[{ }^{\circ} \mathrm{C}\right]$ & 120 & 160 & 200 \\
Extraction time $[\mathrm{min}]$ & 15 & 25 & 35 \\
$\mathbf{c}(\mathrm{HCl})[\%]$ & 0 & 0.75 & 1.5 \\
\hline
\end{tabular}

The response variables were fitted to the following second-order polynomial model (Eq. (4)) which is generally able to describe relationship between the responses and the independent variables:

$$
\begin{gathered}
\beta_{i} X_{i}+\sum_{i=1}^{3} \beta_{i i} X_{i}^{2}+\sum_{i<j=1}^{3} \sum_{i j} X_{i} X_{j} \\
Y=\beta_{0}+\sum_{i=1}^{3}
\end{gathered}
$$

where $Y$ represents the response variable, $X_{i}$ and $X_{j}$ are the independent variables affecting the response, and $\beta_{0}, \beta_{\mathrm{i}}, \beta_{\mathrm{ii}}$, and $\beta_{\mathrm{ij}}$ are the regression coefficients for intercept, linear, quadratic and interaction terms, respectively. Optimal extraction conditions were determined considering total phenolic and total flavonoid content, and antioxidant activity simultaneously as responses. Treatment of multiple responses and selection of optimal conditions were based on desirability function $\mathrm{D}^{28}$ The experimental design and multiple linear regression analysis were performed using Design-Expert v.7 Trial (Stat-Ease, Minneapolis, Minnesota, USA). The fitness of the polynomial model equation was expressed by the coefficient of determination $\left(R^{2}\right)$ and its statistical significance was confirmed by $F$-test at a probability $(p)$ of 0.05 .

\section{Results and Discussion}

\section{1. Extraction Solvent}

Extraction is the first and important step in isolation and purification of bioactive compounds from herbal mate- 
rial. Maceration, traditional extraction method, is influenced by several factors such as type and concentration of solvent, solid/liquid ratio, temperature, extraction time, particle size of solute, $\mathrm{pH}$, etc. Ethanol is considered a suitable solvent for extraction of phenols from various sources. ${ }^{29,30}$ This is due to the wide range of phenols that the aqueous ethanol mixtures can dissolve. For dried chokeberry dust, a wide range of ethanol concentration was tested with the result of $50 \%$ ethanol being superior regarding yields of TP, TF and MA. ${ }^{31}$ Also in our study, selection of the most appropriate ethanol concentration was based on the yields of TP, TF and MA. Extraction yield for each group of compounds is presented in Fig. 1, from where it could be seen that $50 \%$ ethanol provided highest yields of TP and TF and MA. Several authors also reported that the use of medium concentration of ethanol (50\%) resulted in higher TP yields compared with other ethanol/water ratios. ${ }^{32,33}$

Previous studies reported that binary solvent system, containing hydro-organic solvents, was superior comparing to mono-component solvent system in the extraction of phenolic compounds. ${ }^{34,35}$ Water is responsible for swelling of plant material, while ethanol plays a key role in disrupting the bonding between the solutes and plant matrix thus enabling improved mass transfer of the compounds. Ćujić et al. ${ }^{33}$ investigated effects of extraction time $(15,30$, 60 and $90 \mathrm{~min}$ ) on total phenolic and total anthocyanins contents of aronia dried fruit and concluded that extraction time was not relevant regarding yields of TP and MA. In present study, duration of maceration was fixed $(24 \mathrm{~h})$.

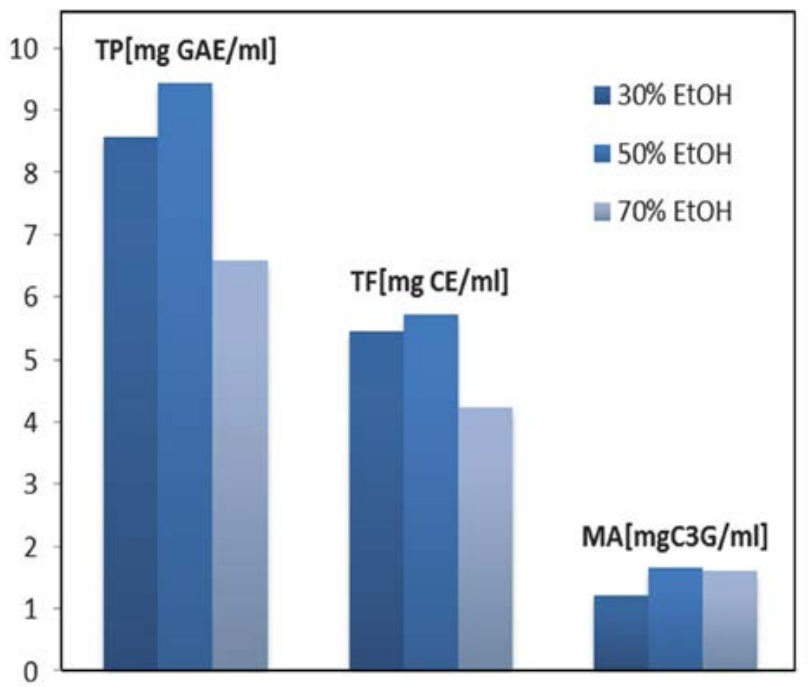

Figure 1. Extraction yields of desirable groups of compounds obtained with different concentration $(30,50$ and $70 \%)$ of ethanol for $24 \mathrm{~h}$

\subsection{Effects of Extraction Parameters on Total Phenolics Content}

It is known that processing of aronia berries into juice can significantly affect its polyphenol composition. However, due to their astringent taste and storage issue, most of the bioavailability tests and clinical trials are conducted with juices instead of berries. ${ }^{36} \mathrm{TP}$ obtained in chokeberry subcritical extracts varied from 13.1579 to
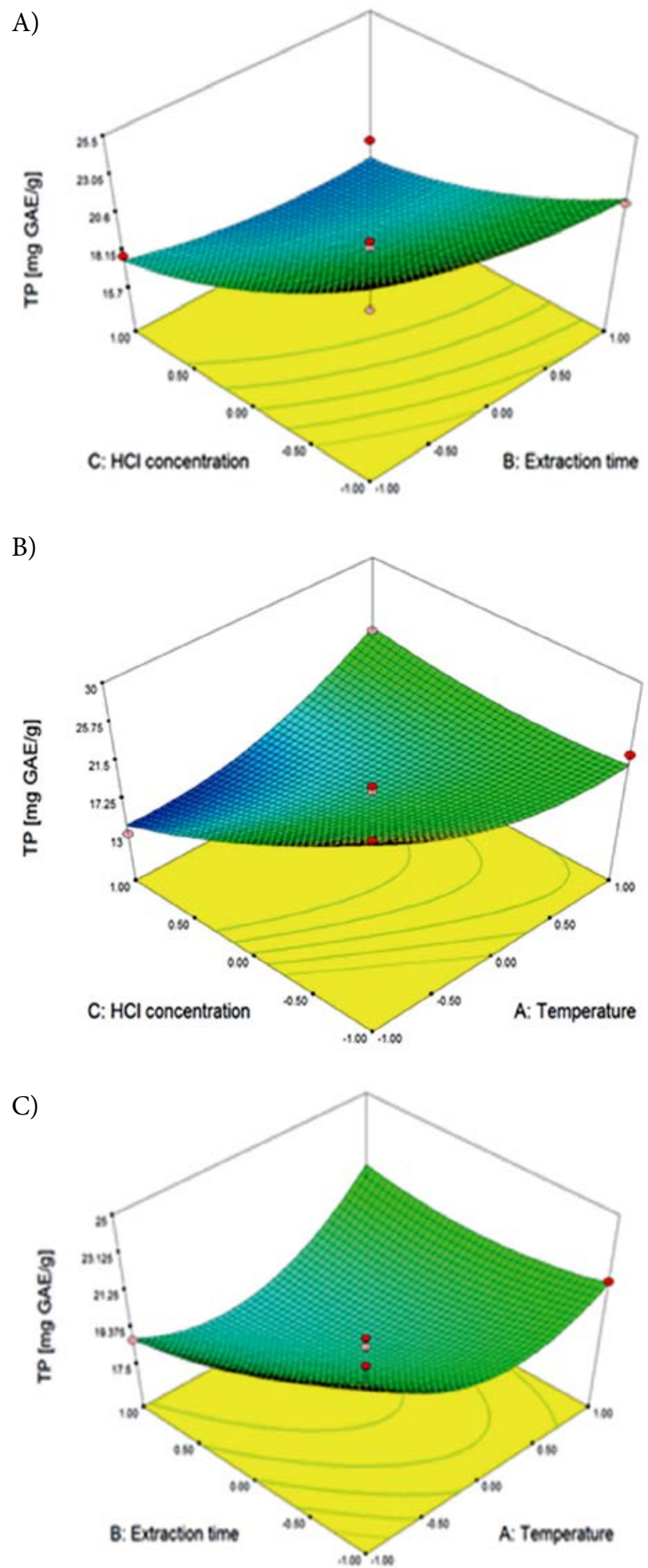

Figure 2. Response surface plots showing combined effects of process variables: (A) $\mathrm{HCl}$ concentration and extraction time, (B) $\mathrm{HCl}$ concentration and temperature and $(\mathrm{C})$ extraction time and temperature on total phenolics content 
Table 2. Box-Behnken design of the three-level and three-variables and observed responses under different experimental conditions

\begin{tabular}{|c|c|c|c|c|c|c|c|}
\hline \multicolumn{4}{|c|}{ Independent variables } & \multicolumn{4}{|c|}{ Investigated responses } \\
\hline Run & $\begin{array}{c}\mathrm{X}_{1} \\
\text { Temperature }\left[{ }^{\circ} \mathrm{C}\right]\end{array}$ & $\begin{array}{c}\mathbf{X}_{2} \\
\text { Time }[\mathbf{m i n}]\end{array}$ & $\begin{array}{c}\mathbf{X}_{3} \\
\mathrm{c}(\mathrm{HCl})[\%]\end{array}$ & TP [mg GAE/g] & $\mathrm{TF}[\mathrm{mg} \mathrm{CE} / \mathrm{g}]$ & $\mathrm{IC}_{50}[\mathrm{mg} / \mathrm{ml}]$ & MA [mg C3G/g] \\
\hline 1 & $160(0)$ & $15(-1)$ & $1.5(1)$ & 17.8520 & 4.1595 & 0.1140 & 0.0401 \\
\hline 2 & $120(-1)$ & $25(0)$ & $0(-1)$ & 29.5536 & 22.1000 & 0.0361 & 0.3473 \\
\hline 3 & $120(-1)$ & $15(-1)$ & $0.75(0)$ & 24.9044 & 14.8682 & 0.0664 & 0.2672 \\
\hline 4 & $160(0)$ & $25(0)$ & $0.75(0)$ & 17.9643 & 4.9700 & 0.0822 & 0.0508 \\
\hline 5 & $160(0)$ & $25(0)$ & $0.75(0)$ & 18.3911 & 5.3776 & 0.1125 & 0.0574 \\
\hline 6 & $200(1)$ & $15(-1)$ & $0.75(0)$ & 21.8050 & 11.2604 & 0.0827 & 0.0628 \\
\hline 7 & $200(1)$ & $35(1)$ & $0.75(0)$ & 20.6595 & 6.2840 & 0.0746 & 0.0908 \\
\hline 8 & $160(0)$ & $25(0)$ & $0.75(0)$ & 18.8627 & 5.8600 & 0.1296 & 0.0735 \\
\hline 9 & $200(1)$ & $25(0)$ & $0(-1)$ & 22.3665 & 14.9685 & 0.0062 & 0.3300 \\
\hline 10 & $200(1)$ & $25(0)$ & $1.5(1)$ & 22.1419 & 9.4655 & 0.0726 & 0.0521 \\
\hline 11 & $160(0)$ & $35(1)$ & $0(-1)$ & 21.3558 & 11.2568 & 0.0214 & 0.1015 \\
\hline 12 & $160(0)$ & $15(-1)$ & $0(-1)$ & 24.1857 & 13.1915 & 0.0291 & 0.4622 \\
\hline 13 & $120(-1)$ & $25(0)$ & $1.5(1)$ & 13.1579 & 8.3000 & 0.1333 & 0.3348 \\
\hline 14 & $160(0)$ & $35(1)$ & $1.5(1)$ & 17.1333 & 5.1340 & 0.1128 & 0.0414 \\
\hline 15 & $120(-1)$ & $35(1)$ & $0.75(0)$ & 18.7504 & 10.9809 & 0.0900 & 0.3256 \\
\hline
\end{tabular}

Table 3. Estimated coefficients of the fitted second-order polynomial model for TP, TF, IC50 and MA, and analysis of variance (ANOVA) for the investigated systems

\begin{tabular}{|c|c|c|c|c|}
\hline \multirow[t]{2}{*}{ Term } & \multicolumn{4}{|c|}{ Regression coefficient } \\
\hline & TP [mg GAE/g] & $\mathrm{TF}[\mathrm{mg} \mathrm{CE} / \mathrm{g}]$ & IC50 [mg/ml] & MA [mg C3G/g] \\
\hline$\beta_{0}$ & 18.4060 & 5.4025 & 0.1081 & 0.0606 \\
\hline \multicolumn{5}{|l|}{ Linear } \\
\hline$\beta_{1}$ & 0.0758 & $-1.7838^{\star}$ & -0.0112 & $-0.0924^{\star}$ \\
\hline$\beta_{2}$ & $-1.3560^{\star}$ & $-1.2280^{\star *}$ & $8.2500 \mathrm{E}-004$ & -0.0341 \\
\hline$\beta_{3}$ & $-3.3971^{\star}$ & $-4.3072^{\star}$ & $0.0425^{\star}$ & $-0.0966^{\star}$ \\
\hline \multicolumn{5}{|c|}{ Cross product } \\
\hline$\beta_{12}$ & 1.2521 & -0.2723 & $-7.9425 \mathrm{E}-003$ & $-7.5980 \mathrm{E}-003$ \\
\hline$\beta_{13}$ & $4.0428^{\star}$ & $2.0743^{\star}$ & $-7.6975 \mathrm{E}-003$ & -0.0663 \\
\hline$\beta_{23}$ & 0.5278 & 0.7273 & $1.6225 \mathrm{E}-003$ & $0.0905^{\star *}$ \\
\hline \multicolumn{5}{|l|}{ Quadratic } \\
\hline$\beta_{11}$ & $2.3985^{\star}$ & $5.3594^{*}$ & -0.0185 & $0.1154^{*}$ \\
\hline$\beta_{22}$ & 0.7253 & 0.0864 & -0.0112 & 0.0107 \\
\hline$\beta_{33}$ & 1.0004 & $2.9465^{\star}$ & $-0.0276^{\star \star}$ & $0.0901^{\star *}$ \\
\hline$R^{2 \mathrm{a}}$ & 0.9629 & 0.9682 & 0.8970 & 0.8959 \\
\hline $\mathrm{CV}^{\mathrm{b}}$ & 6.0900 & 15.0400 & 27.6200 & 45.6000 \\
\hline$p_{m}-$ Value $^{\mathrm{c}}$ & $<0.0050$ & $<0.0050$ & $<0.0500$ & $<0.0500$ \\
\hline$p_{l f}-$ Value $^{\mathrm{d}}$ & 0.0759 & 0.0535 & 0.6490 & 0.01270 \\
\hline
\end{tabular}

${ }^{\star}$ Significant at $5 \%$; ${ }^{*}$ Significant at $10 \%$; a Coefficient of multiple determination; b Coefficient of variance [\%]; c Probability of $\mathrm{F}$ value for the model; $\mathrm{d}$ Probability of $\mathrm{F}$ value for the lack of fit

$29.5536 \mathrm{mg} \mathrm{GAE} / \mathrm{g}$, while TP obtained by maceration with 30, 50 and $70 \%$ ethanol provided notably higher values, 306.1392; 351.0761 and $273.3627 \mathrm{mg} \mathrm{GAE} / \mathrm{g}$, respectively. The lowest yield for investigated response was obtained at temperature of $120^{\circ} \mathrm{C}$, extraction time of $25 \mathrm{~min}$ and added $1.5 \% \mathrm{HCl}$, while TP $(29.5536 \mathrm{mg} \mathrm{GAE} / \mathrm{g})$ was found to be the highest at temperature of $120^{\circ} \mathrm{C}$, extraction time of $25 \mathrm{~min}$ and absence of acidifier. This indicates weak influence of both temperature and extraction time on TP yield. Ju and Howard ${ }^{37}$ observed $31 \%$ decrease of total phenolics in red grape skin subcritical extracts, when temperature increased from 100 to $160{ }^{\circ} \mathrm{C} .{ }^{37}$ Grunovaite et al. ${ }^{38}$ reported TP yield (182.89 $\mathrm{mg} \mathrm{GAE} / \mathrm{g}$ extract) of chokeberry pomace subcritical extract obtained at $130^{\circ} \mathrm{C}$. Combined influence of SWE parameters on the TP is presented in Fig. 2. 
According to regression coefficients (Table 3), except for linear terms of extraction time and $\mathrm{HCl}$ concentration, all other effects of parameters were positive on TP content in SWE extracts. According to $p$-values for the regression coefficients, linear term of time, interaction term between temperature and $\mathrm{HCl}$ concentration and quadratic term of temperature exhibited significant influence $(p<0.05)$. The most influental was linear term of $\mathrm{HCl}$ concentration $(p<$ 0.0006). Coefficient of multiple regression for this model $(p<0.0045)$ indicates excellent correlation between experimental and predicted values which was further supported by CV (6.09\%) and $R^{2}(0.9629)$.

\section{3. Effects of Extraction Parameters on Total Flavonoids Content}

Significant losses of flavonol glycosides occurred during the pressing operation, with $39-49 \%$ of the compounds being retained in the cake. The less polar quercetin hexosides (galactoside and glucoside) were retained to a greater extent in the cake than the more polar quercetin diglycosides. According to Wilkes et al., ${ }^{36}$ the majority of the non-polar quercetin aglycone was retained in the cake, while only $27 \%$ was expressed into the juice.

Experimental values of TF obtained under different SWE conditions are presented in Table 2. TF recovered in chokeberry subcritical extracts varied from 4.1595 to $22.1000 \mathrm{mg}$ CE/g while TF obtained by maceration with 30,50 and $70 \%$ ethanol provided significantly higher values, $194.4607 ; 213.1274$ and 176.1847 , respectively. The highest value $(22.1000 \mathrm{mg} \mathrm{CE} / \mathrm{g})$ of investigated response was obtained under temperature of 120 ${ }^{\circ} \mathrm{C}$, extraction time of $25 \mathrm{~min}$ and absence of acidifier, the same conditions as it was the case with TP content. This is consistent with previous findings, where total flavonol content increased 3.7 -fold from 100 to $120^{\circ} \mathrm{C}$ in red grape skin subcritical extracts. However, the lowest TF content was observed under temperature of $160^{\circ} \mathrm{C}$, extraction time of $15 \mathrm{~min}$ and with added $1.5 \% \mathrm{HCl}$. This is in accordance with literature, where total flavonol content of subcritical extracts declined $30 \%$ when temperature increased from 120 to $160{ }^{\circ} \mathrm{C} .{ }^{37}$ Combined influence of SWE parameters on the TF is presented in Fig. 3.

Statistical coefficients $\left(R^{2}=0.9682, \mathrm{CV}=15.04 \%\right)$ indicated that this model represented satisfying fit to the experimental results. All three linear terms exhibited negative effect on TF content. According to $p$-values for the regression coefficients, linear terms showed significant influence while $\mathrm{HCl}$ concentration was the most influental $(p<0.0004)$ parameter, as it was the case with TP content. Interaction term between temperature and $\mathrm{HCl}$ concentration showed highly significant $(p<0.05)$ influence on TF content. Also, quadratic terms of temperature and $\mathrm{HCl}$ concentration exhibited highly significant $(p<0.05)$ influence.

\section{4. Effects of Extraction Parameters on Monomeric Anthocyanins}

Wilkes et al. ${ }^{36}$ reported that anthocyanins were more susceptible to losses during processing than flavo-
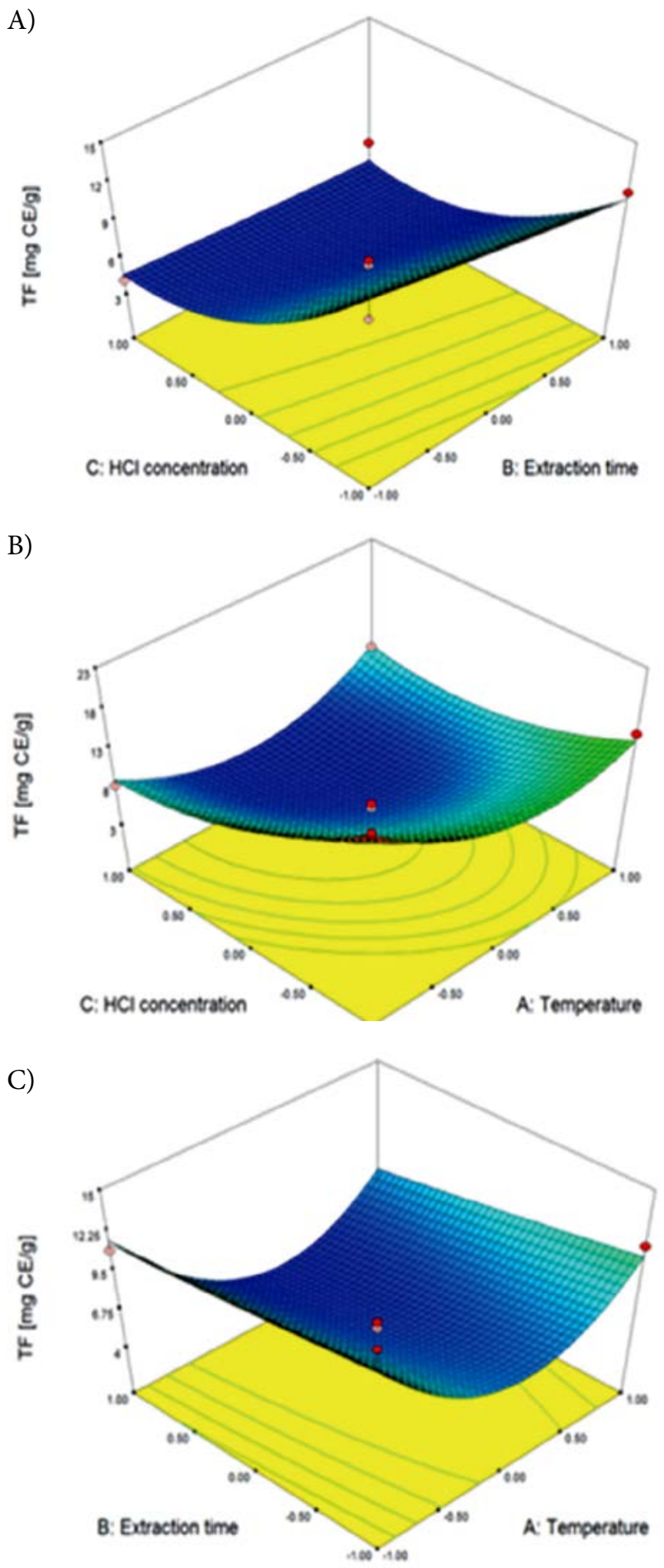

Figure 3 Response surface plots showing combined effects of process variables: (A) $\mathrm{HCl}$ concentration and extraction time, (B) $\mathrm{HCl}$ concentration and temperature and $(\mathrm{C})$ extraction time and temperature on total flavonoids content 
nols, total proanthocyanidins, and hydroxycinnamic acids as a result of thermal degradation, proven by increased levels of protocatechuic acid and phloroglucinaldehyde. The juice pressing step resulted in losses of all polyphenols due to physical removal of skins, while anthocyanins

A)

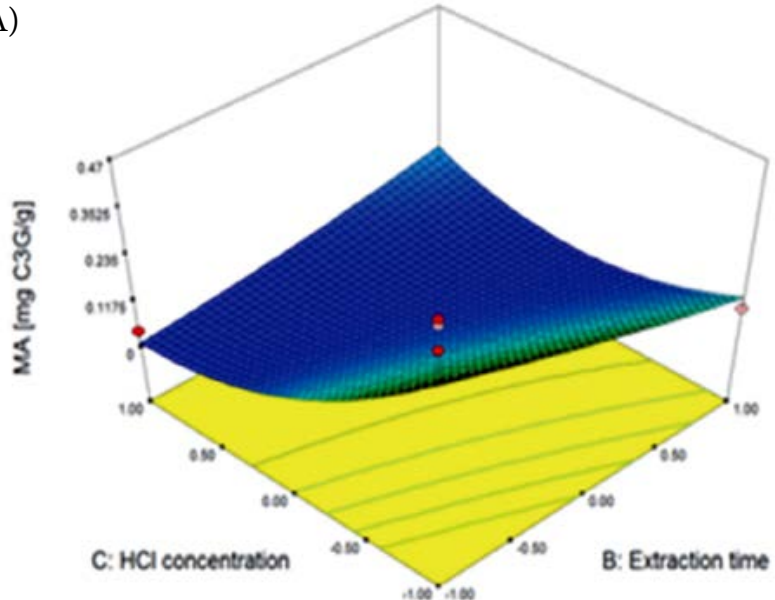

B)

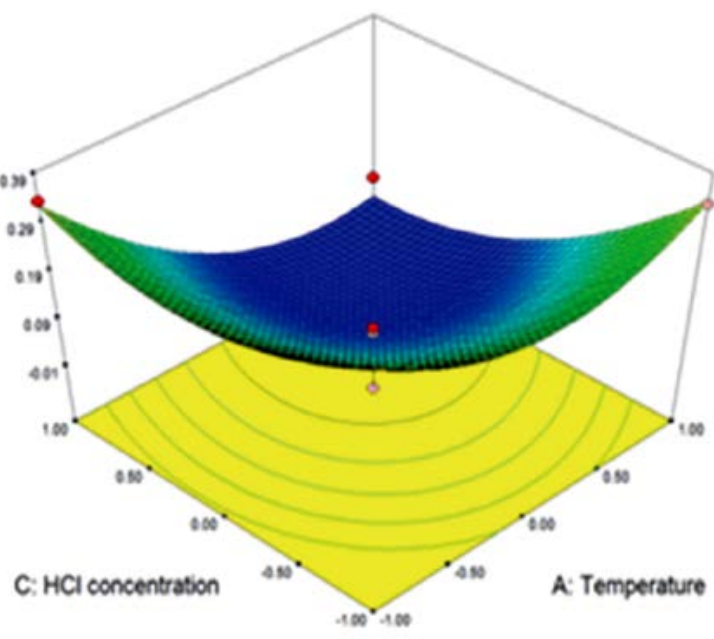

C)

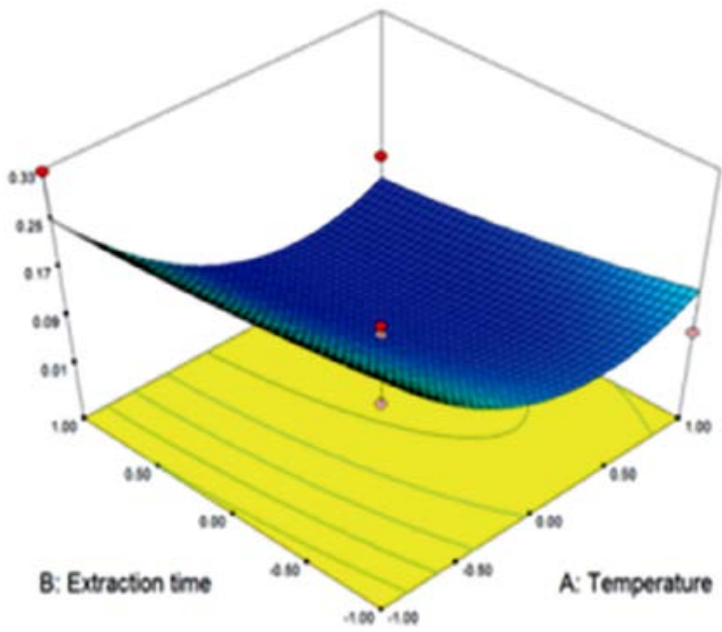

Figure 4 Response surface plots showing combined effects of process variables: (A) $\mathrm{HCl}$ concentration and extraction time, (B) $\mathrm{HCl}$ concentration and temperature and $(\mathrm{C})$ extraction time and temperature on monomeric anthocyanins yield and total proanthocyanidins were retained in the cake to a greater extent than hydroxycinnamic acids and flavonols. The cake contained 52, 51, 54 and $54 \%$ of the levels of cyanidin 3-galactoside, cyanidin 3-glucoside, cyanidin 3 -arabinoside and cyanidin 3-xyloside found in the enzyme treated mash, respectively. ${ }^{36}$ The importance of anthocyanins remaining within the cakes is quite significant, as Kalt et al. ${ }^{39}$ claimed that antioxidant capacity in blueberries is mainly due to anthocyanins, although other phenolics also contribute to its antioxidant activities. ${ }^{39}$ As aronia cake is mainly composed of fruit skins, which are high in pigment, rapid mass transport of the anthocyanins from the substrate using subcritical water facilitates fast and effective extraction process. ${ }^{40}$ Experimentally obtained yields for monomeric anthocyanins under different SWE conditions are presented in Table 2, while regression coefficients and statistical analysis of investigated response are presented in Table 3. Extraction parameters demonstrated similar influence to $\mathrm{TF}$ and MA $(r=0.702)$, which was rather expected due to anthocyanins being a class of flavonoids. In order to improve understanding of multiple influences of all independent variables, response surface plots were created according to Eq. (2) (Fig.4).

In contrast to the results obtained by Ju and Howard, ${ }^{37}$ where acidified water used as solvent provided maximum extraction of total anthocyanins (3-glucosides of delphinidin, cyanidin, petunidin, peonidin and malvidin) at $80-100{ }^{\circ} \mathrm{C},{ }^{38}$ the highest MA yield $(0.0462 \mathrm{mg}$ $\mathrm{C} 3 \mathrm{G} / \mathrm{mL}$ ) in our case was observed at temperature of 160 ${ }^{\circ} \mathrm{C}$, extraction time of $15 \mathrm{~min}$ and absence of acidifier. The highest MA yield ( $1.6590 \mathrm{mg} \mathrm{C} 3 \mathrm{G} / \mathrm{mL})$ obtained by maceration with $50 \%$ ethanol was above 35 -fold higher than the highest MA yield acquired with SWE. The lowest MA yield $(0.0040 \mathrm{mg} \mathrm{C} 3 \mathrm{G} / \mathrm{mL})$ was obtained at temperature of $160{ }^{\circ} \mathrm{C}$, extraction time of $15 \mathrm{~min}$ and addition of $1.5 \% \mathrm{HCl}$. Above 414 -fold difference between the lowest and the highest MA yields suggests that absence/presence of acidifier has a crucial role in MA yield. Most extraction procedures use acidified solutions of ethanol, methanol, acetone, water, and acetone/methanol/water mixtures, which denature cellular membranes and facilitate solubilization of anthocyanins. ${ }^{33}$ Regarding TP, TF and MA yields, the lowest responses were obtained when 1.5\% $\mathrm{HCl}$ was added, while the highest responses were observed when acidifier was absent. Although hydrochloric acid $(<1.0 \%)$ is recommended for anthocyanin extraction, addition of excess acid can lead to hydrolysis of labile, acyl and sugar residues. ${ }^{42}$ Ramic et al. reported highest MA yield $(2.26 \mathrm{mg} \mathrm{C} 3 \mathrm{G} / \mathrm{mL}$ ) obtained by ultrasound assisted extraction (UAE) of black chokeberry at temperature of $70{ }^{\circ} \mathrm{C}$ and extraction time of $60 \mathrm{~min} .{ }^{31}$ The highest MA yield obtained by UAE was more than 48 -fold higher than the highest MA yield in subcritical chokeberry extract at temperature of $160^{\circ} \mathrm{C}$ and extraction time of $15 \mathrm{~min}$. Total anthocyanins were degraded at tempera- 
tures $>100{ }^{\circ} \mathrm{C}$ (especially at $140{ }^{\circ} \mathrm{C}$ ), indicating that 100 ${ }^{\circ} \mathrm{C}$ was the optimum SWE temperature for isolating anthocyanins using acidified water. ${ }^{37}$ Therefore, elevated temperature $\left(160^{\circ} \mathrm{C}\right)$ could be responsible for notably lower MA yield obtained by SWE in comparison with UAE and maceration.

According to regression coefficients, the effects of linear terms of SWE parameters were all negative on MA content in subcritical extracts. Linear terms of temperature and $\mathrm{HCl}$ concentration showed highly significant influence $(p<0.05)$ as well as quadratic term of temperature. The total anthocyanin content of subcritical extracts obtained from red grape skin declined 40\% from 110 to 160 ${ }^{\circ} \mathrm{C},{ }^{37}$ indicating that elevated extraction temperature could cause rapid degradation and even discoloration of anthocyanins in some cases. ${ }^{42}$ The thermal degradation of anthocyanins follows 1 st order reaction kinetics, ${ }^{43}$ hence high-temperature short-time processing is recommended for maximizing the retention of anthocyanins in foods ${ }^{41}$. Therefore, SWE was conducted over the temperature range of 120 to $200^{\circ} \mathrm{C}$ in $40^{\circ} \mathrm{C}$ increments for a short time (15$35 \mathrm{~min}$ ) ensuring high superficial fluid velocity through the extraction cell. Interaction term between extraction time and $\mathrm{HCl}$ concentration together with quadratic term of $\mathrm{HCl}$ concentration exhibited moderately significant influence $(p<0.1)$.

\section{5. Effects of Extraction Parameters on Antioxidant Activity}

Increasing temperature from 100 to $160^{\circ} \mathrm{C}$ resulted in a linear increase in ORAC values in subcritical extracts derived from red grape skin. The ORAC value of extract obtained by conventional methanol extraction was greater than the ORAC values obtained by SWE from 100 to 140 ${ }^{\circ} \mathrm{C}$, but less than ORAC values obtained by SWE from 140 to $160{ }^{\circ} \mathrm{C}$. The ORAC values showed negative correlation with total anthocyanins in subcritical extracts, suggesting that anthocyanins are not responsible for antioxidant capacity. ${ }^{37}$

In this study, antioxidant capacity expressed as $\mathrm{IC}_{50}$ value ranged from 0.0062 to $0.1333 \mathrm{mg} / \mathrm{mL}$. The highest antioxidant activity $(0.0062 \mathrm{mg} / \mathrm{mL})$ was observed at temperature of $200{ }^{\circ} \mathrm{C}$, extraction time of $25 \mathrm{~min}$ and absence of acidifier, while the lowest activity $(0.1333 \mathrm{mg} / \mathrm{mL})$ was obtained at $120^{\circ} \mathrm{C}, 25 \mathrm{~min}$ and with added $1.5 \% \mathrm{HCl}$. These results suggest that temperature and absence/presence of acidifier are the most influence parameters affecting antioxidant capacity. Response surface plots which visualize influence of SWE parameters on antioxidant activity are presented in Fig. 5.

In the case of $\mathrm{IC}_{50}$, as it was the case with anthocyanins, linear term of $\mathrm{HCl}$ concentration showed highly significant $(p<0.05)$ influence, while quadratic term of $\mathrm{HCl}$ concentration showed moderately significant $(p<0.1)$ influence.
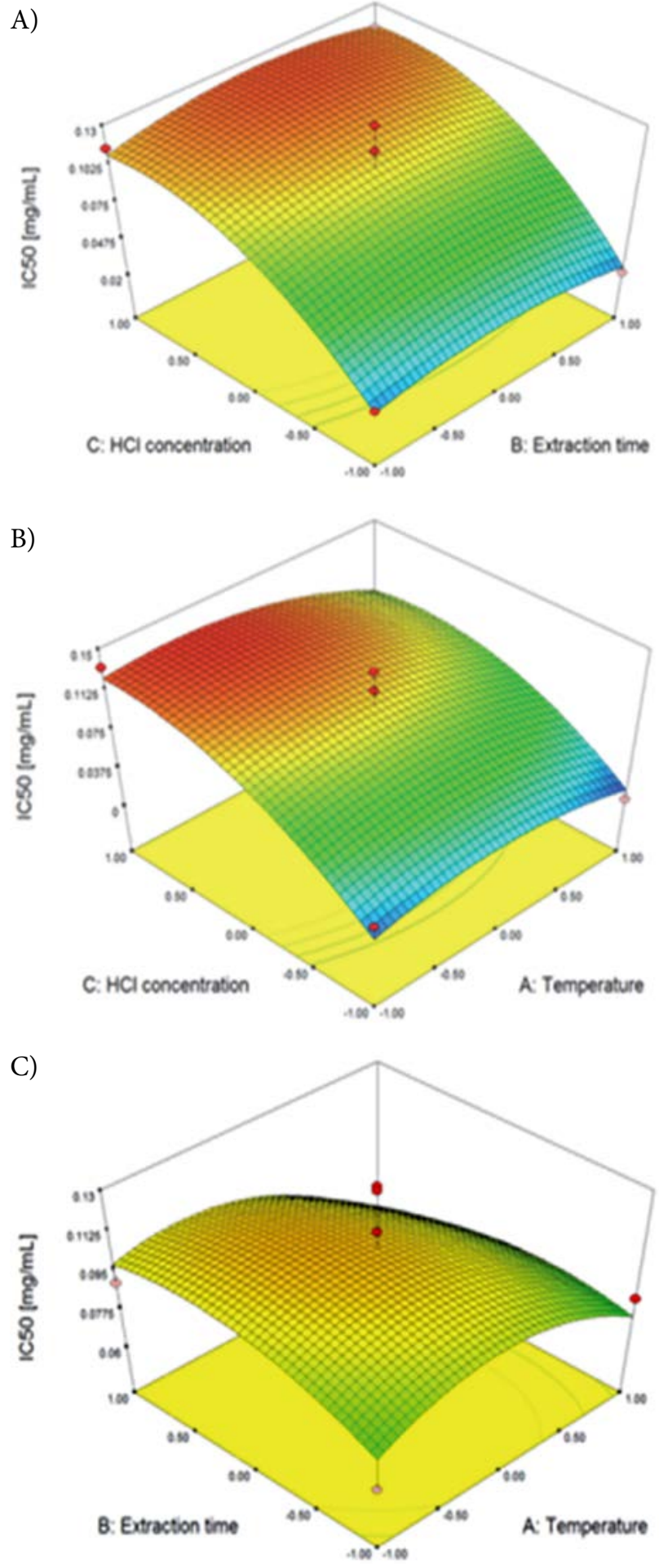

Figure 5 Response surface plots showing combined effects of process variables: (A) $\mathrm{HCl}$ concentration and extraction time, (B) $\mathrm{HCl}$ concentration and temperature and $(\mathrm{C})$ extraction time and temperature on $\mathrm{IC}_{50}$ value

\section{6. Optimization of SWE Parameters for Maximizing Yields of Polyphenolics}

One of the main goals of this investigation was to maximize extraction yields for $\mathrm{TP}, \mathrm{TF}$ and $\mathrm{MA}$, and to 
minimize $\mathrm{IC}_{50}$ value within the range of each extraction parameter. Determination of optimal conditions and predicted values was based on desirability function which was 1 , the most desirable response. ${ }^{27}$ The optimized SWE conditions for maximum response of TP, TF and MA, and minimum response of $\mathrm{IC}_{50}$ were temperature of $120.4{ }^{\circ} \mathrm{C}$, extraction time of $15.2 \mathrm{~min}$ and absence of acidifier. Results of this work were in accordance with previous studies where temperature of $120^{\circ} \mathrm{C}$ was detected as optimal for SWE of anthocyanins from different berry pomaces and seeds. ${ }^{37,40}$ The predicted values of TP, TF, MA and $\mathrm{IC}_{50}$ value at optimal conditions were $32.8863 \mathrm{mg} \mathrm{GAE} / \mathrm{g}, 23.5164$ $\mathrm{mg} \mathrm{CE} / \mathrm{g}, 0.5124 \mathrm{mg} \mathrm{C} 3 \mathrm{G} / \mathrm{g}$ and $0.0055 \mathrm{mg} / \mathrm{mL}$, respectively.

According to particularly high values of coefficients of multiple determination $\left(R^{2}\right)$ for TP and TF $(0.9629$ and 0.9682 ), excellent fit between experimental and values predicted by the model is indicated. Although $R^{2}$ was relatively high in case of $\mathrm{IC}_{50}(0.8970)$ and MA (0.8959), it was still significantly lower comparing to other responses. However, for all four responses, mathematical models were statistically acceptable due to significant regression $\left(p_{m}<0.05\right)$ and non-significant lack of fit ( $\left.p_{l f}>0.05\right)$, except for MA where lack of fit was significant $\left(p_{l f}=0.0127\right)$. Furthermore, coefficient of variance, which represents dispersion degree of the data, is rather low $(\mathrm{CV} \leq 15 \%)$ in all models and supports good fitness of the model providing better reproducibility except in the case of $\mathrm{MA}$ and $\mathrm{IC}_{50}$.

\section{Conclusions}

Previously published data on antioxidant capacity indicators of chokeberry cake are rather scarce. Although aronia pomace is by far the richest source of total phenolics, aronia cake may serve as an alternative low-cost raw material for extraction of dietary antioxidants. The major drawbacks of conventional extraction techniques in general are long time, excessive cost, use of large quantity of organic solvent, poor extraction selectivity and generation of toxic organic waste. These obstacles could be overcome by employing SWE.

The second-order polynomial model has proven to be adequate for mathematical description of SWE of several groups of polyphenolic compounds. Therefore, optimization of extraction conditions in order to simultaneously provide maximum yields for TP, TF and MA and, minimum $\mathrm{IC}_{50}$ value was successfully performed using RSM coupled with BBD. Since statistical and graphical analysis showed that $\mathrm{HCl}$ concentration was the most influential factor for all four responses, absence of acidifier was determined as optimal for extraction of polyphenolic compounds. The optimized SWE conditions, for maximum response of $\mathrm{TP}, \mathrm{TF}$ and $\mathrm{MA}$, and minimum response of $\mathrm{IC}_{50}$, were temperature of $120.4^{\circ} \mathrm{C}$, extraction time of 15.2 $\mathrm{min}$ and absence of acidifier. The predicted values of $\mathrm{TP}$,
TF, MA and $\mathrm{IC}_{50}$ at these conditions were: $32.8863 \mathrm{mg}$ GAE/g, $23.5164 \mathrm{mg} \mathrm{CE} / \mathrm{g}, 0.5124 \mathrm{mg} \mathrm{C} 3 \mathrm{G} / \mathrm{g}$ and 0.0055 $\mathrm{mg} / \mathrm{mL}$, respectively.

Recognizing the obtained results it can beob concluded that aronia fruit dust, discharged as by-product from filter tea factory, can serve as a valuable source of polyphenols when SWE is applied. Although high-temperature short-time processing is suitable for maximizing the retention of anthocyanins in plant matrices, SWE is not the optimal technology for recovery of monomeric anthocyanins from aronia fruit dust providing notably lower yields in comparison with UAE and maceration.

\section{References}

1. S. E. Kulling, H. M. Rawel, Planta Med. 2008, 74, 1625-1634. DOI:10.1055/s-0028-1088306

2. L. Jakobek, M. Seruga, M. Medvidovic-Kosanovic, I. Novak, Dtsch. Lebensmitt. Rundsch. 2007, 103, 58-64.

3. J. Oszmiański, A. Wojdylo, Eur. Food Res. Technol. 2005, 221, 809-813. DOI:10.1007/s00217-005-0002-5

4. M. P. Kähkönen, A. I. Hopia, H. J. Vuorela, J. P. Rauha, K. Pihlaja, T. S. Kujala, M. Heinonen, J. Agric. Food Chem. 1999, 47, 3954-3962. DOI:10.1021/jf9901461

5. P. N. Denev, C. G. Kratchanov, M. Ciz, A. Lojek, M. G. Kratchanova, Compr. Rev. Food Sci. Food Saf. 2012, 11, 471-489. DOI:10.1111/j.1541-4337.2012.00198.x

6. A. Kokotkiewicz, Z. Jaremicz, M. Luczkiewicz, J. Med. Food. 2010, 13, 255-269. DOI:10.1089/jmf.2009.0062

7.X. L. Wu, L. W. Gu, R. L. Prior, S. McKay, J. Agric. Food Chem. 2004, 52, 7846-56 DOI:10.1021/jf0486850

8. A. Nawirska, M. Kwasniewska, Food Chem. 2005, 91, 221-5 DOI:10.1016/j.foodchem.2003.10.005

9. S. Vidovic, D. Cvetkovic, M. Ramic, M. Dunjic, R. Malbaša, A. Tepic, Z. Šmic, A. Velicanski, S. Jokic, Ind. Crops Prod. 2013, 50, 338-345. DOI:10.1016/j.indcrop.2013.08.005

10. Dai, J., \& Mumper, R. J. Molecules. 2010, 15(10), 7313-7352. DOI: $10.3390 /$ molecules 15107313

11. R. S. Ayala, M. L. De Castro, Food Chem. 2001, 75(1), 109113. DOI:10.1016/S0308-8146(01)00212-6

12. C. C. Teo, S. N. Tan, J. W. Yong, C. S. Hew, E. S. Ong, J. Chromatogr. A. 2010, 1217(16), 2484-2494.

DOI:10.1016/j.chroma.2009.12.050

13. S. Erşan, O. G. Üstündağ, R. Carle, R. M. Schweiggert, Food Chem. 2018, 253, 46-54.

DOI:10.1016/j.foodchem.2018.01.116

14. J. Vladić, O. Canli, B. Pavlić, Z. Zeković, S. Vidović, M. Kaplan, J. Supercrit. Fluids. 2017, 120, 86-94.

DOI:10.1016/j.supflu.2016.10.016

15. P. P. Singh, M. D. Saldaña, Food Res. Int. 2011, 44(8), 2452 2458. DOI:10.1016/j.foodres.2011.02.006

16. B. Aliakbarian, A. Fathi, P. Perego, F. Dehghani, J. Supercrit. Fluids. 2012, 65, 18-24. DOI:10.1016/j.supflu.2012.02.022

17. P. Budrat, A. Shotipruk, Sep. Purif. Technol. 2009, 66(1), 125129. DOI:10.1016/j.seppur.2008.11.014 
18. P. Rangsriwong, N. Rangkadilok, J. Satayavivad, M. Goto, A. Shotipruk, Sep. Purif. Technol. 2009, 66(1), 51-56.

DOI:10.1016/j.seppur.2008.11.023

19. M. J. Ko, C. I. Cheigh, S. W. Cho, M. S. Chung, J. Food Eng. 2011, 102(4), 327-333.

DOI:10.1016/j.jfoodeng.2010.09.008

20. S. Ponnusamy. H. K. Reddy, T. Muppaneni. C. M. Downes, S. Deng, Bioresour. Technol. 2014, 170. 454-461.

DOI:10.1016/j.biortech.2014.07.072

21. Z. Zeković, S. Vidović, J. Vladić, R. Radosavljević, A. Cvejin, M. A. Elgndi, B. Pavlić, J. Supercri. Fluids. 2014, 95, 560-566.

22. V. L. Singleton, J. A. Rossi, Am. J. Enology Vitic. 1965, 16, 144-158.

23. Harborne, J. B. (1989). Methods in Plant Biochemistry, Plant Phenolics, vol. 1, Academic Press Ltd., London.

24. M. F. Abu Bakar, M. Mohamed, A. Rahmat, J. Fry, Food Chem. 2009, 113, 479-483. DOI:10.1016/j.foodchem.2008.07.081

25. P. Dzomba, Afr. J. Agric. Res. 2013, 25, 3330-3333.

26. J. C. Espin, C. Soler-Rivas, H. J. Wichers, C. Garcia-Viguera, J. Agric. Food Chem. 2000, 48, 1588-1592.

DOI:10.1021/jf9911390

27. D. Baş, I. H. Boyac1, J. Food Eng. 2007, 78(3), 836-845.

DOI:10.1016/j.jfoodeng.2005.11.024

28. R. H. Myers, D. C. Montgomery, C. M. Anderson-Cook, Response Surface Methodology: Process and Product Optimization Using Designed Experiments, third ed., Wiley, New Jersey, 2009.

29. T. Bahorun, A. Luximon-Ramma, A. Crozier, O. I. Aruoma, J. Sci. Food Agric. 2004, 84(12), 1553-1561.

DOI: $10.1002 /$ jsfa. 1820

30. N. E. Durling, O. J. Catchpole, J. B. Grey, R. F. Webby, K. A. Mitchell, L. Y. Foo, N. B. Perry, Food Chem. 2007, 101(4), 1417-1424. DOI:10.1016/j.foodchem.2006.03.050
31. M. Ramić, S. Vidović, Z. Zeković, J. Vladić, A. Cvejin, B. Pavlić, Ultrason. Sonochem. 2015, 23, 360-368.

DOI:10.1016/j.ultsonch.2014.10.002

32. L. G. d'Alessandro, K. Kriaa, I. Nikov, K. Dimitrov, Sep. Purif. Technol. 2012, 93, 42-47. DOI:10.1016/j.seppur.2012.03.024

33. N. Ćujić, K. Šavikin, T. Janković, D. Pljevljakušić, G. Zdunić, S. Ibrić, Food Chem. 2016, 194, 135-142.

DOI:10.1016/j.foodchem.2015.08.008

34. Z. S. Zhang, D. Li, L. J. Wang, N. Ozkan, X. D. Chen, Z. H. Mao, Sep. Purif. Technol. 2007, 57, 17-24.

DOI:10.1016/j.seppur.2007.03.006

35. J. E. Cacace, G. Mazza, J. Food Sci. 2003, 68, 240-248. DOI:10.1111/j.1365-2621.2003.tb14146.x

36. K. Wilkes, L. R. Howard, C. Brownmiller, R. L. Prior, J. Agric. Food Chem. 2013, 62(18), 4018-4025. DOI:10.1021/jf404281n

37. Z. Y. Ju, L. R. Howard, J. Agric. Food Chem. 2003, 51, 5207-13. DOI:10.1021/jf0302106

38. L. Grunovaitė, M. Pukalskienè, A. Pukalskas, P. R. Venskutonis, J. Funct. Foods. 2016, 24, 85-96. DOI:10.1016/j.jff.2016.03.018

39. W. Kalt, J. E. H. McDonald, Donner, J. Food Sci. 2000, 65(3), 390-393. DOI:10.1111/j.1365-2621.2000.tb16013.x

40. J. W. King, R. D. Grabiel, J. D. Wightman, In Proceedings of the $6^{\text {th }}$ Intl. Symposium on Supercritical Fluids (Vol. 1, pp. 28-30), 2003.

41. R. L. Jackman, J. L. Smith, Anthocyanins and betalains. In: Hendry GAF, Houghton JD, editors. Natural food colorants. $2^{\text {nd }}$ ed. Glasgow, U.K.: Blacklie Academic \& Professional, 1996, 244-309. DOI:10.1007/978-1-4615-2155-6_8

42. H. Wang, G. Cao, R. L. Prior, J. Agric. Food Chem. 1997, 45, 304-309. DOI:10.1021/jf960421t

43. B. Cemeroglu, S. Velioglu, S. Isik, J. Food Sci. 1994, 59, 12167. DOI:10.1111/j.1365-2621.1994.tb14680.x

\section{Povzetek}

Odpadne produkte aronije (Aronia melanocarpa L.), ki nastajajo pri proizvodnji čaja v filtrnih vrečkah, smo podvrgli subkritični vodni ekstrakciji (SWE) z namenom izolacije polifenolov in določitve njihovih antioksidativnih lastnosti. Za optimizacijo pogojev smo uporabili Box-Behnken-ovo metodo načrtovanja eksperimentov. Neodvisni parametri so bili temperatura ( $\left.\mathrm{T}, 120-200^{\circ} \mathrm{C}\right)$, čas ekstrakcije (t, 15-35 $\mathrm{min}$ ) in koncentracija hidroklorida (c, 0-1.5 \%). Eksperimentalnim podatkom smo prilagodili polinom 2 . stopnje ter s pomočjo multiple regresijske in analize variance določili njegovo ustreznost kot tudi optimalne pogoje. Optimizirani SWE pogoji, pri katerih so bile dosežene maksimalne koncentracije skupnih fenolov (TP), skupnih flavonoidov (TF) in monomernih antocianinov (MA) ob minimalni vrednosti IC50, so bili: temperatura $120.4^{\circ} \mathrm{C}$, čas ekstrakcije $15.2 \mathrm{~min}$ in odsotnost hidroklorida. Predvidene vrednosti TP, TF, MA in IC50 pri teh pogojih so: $32.8863 \mathrm{mg} \mathrm{GAE} / \mathrm{g}, 23.5164 \mathrm{mg} \mathrm{CE} / \mathrm{g}, 0.5124 \mathrm{mg} \mathrm{C} 3 \mathrm{G} / \mathrm{g}$ in $0.0055 \mathrm{mg} / \mathrm{mL}$. 